\title{
Trans w kultach vodun i katolicyzmie - religioznawcze wyzwanie dla kulturoznawstwa
}

\author{
Recenzja książki: Jakub Bohuszewicz, Od opętania do rytuału. Pojęcie \\ i praktyka transu w kultach vodun i katolicyzmie, Jagiellońskie Monografie \\ Religioznawcze, Wydawnictwo Uniwersytetu Jagiellońskiego, Kraków 2017, \\ 276 stron
}

\author{
Krzysztof Obremski (D) http://orcid.org/0000-0001-6164-9207 \\ Wydział Filologiczny \\ Uniwersytet Mikołaja Kopernika w Toruniu \\ e-mail: obremski@umk.pl
}

Religia to stosunkowo skromny dogmat,
który mówi, że Bóg nie oszalat.

Salvador de Madariaga ${ }^{1}$

Zimą 2018 roku trafiła w moje ręce właśnie wydana książka Od opętania do rytuału. Pojęcie i praktyka transu $w$ kultach vodun $i$ katolicyzmie (opublikowana w ramach serii Jagiellońskie Monografie Religioznawcze). Jej autor Jakub Bohuszewicz - jak można przeczytać na czwartej stronie okładki - zajmuje się biologiczno-kognitywnymi teoriami religii. Tamże również czytam wyimek z recenzji wydawniczej dra hab. Tomasza Sikory:

\footnotetext{
Autorowi udało się powiedzieć coś ważnego, wnoszącego istotny wkład do współczesnych nauk o człowieku. Rozprawa spełnia wymogi stawiane dysertacji naukowej, a zarazem stanowi przykład nauki uprawianej z pasją, odnoszącej się do zagadnień fundamentalnych dla zrozumienia ludzkiej natury.
}

Ostatnie stwierdzenie zachęca również nie-religioznawców do lektury i rozważenia „zagadnień fundamentalnych dla zrozumienia ludzkiej natury”. Niejako tym samym: zagadnień fundamentalnych dla zrozumienia kultury (w książce sygnalizowanych nazwiskami takich myślicieli jak Durkheim, Eliade, Frazer, Freud, Geertz,

${ }^{1}$ Cyt. za: J. Bohuszewicz, Od opętania do rytuału. Pojęcie i praktyka transu w kultach vodun $i$ katolicyzmie, Kraków 2017, s. 199. W dalszej części artykułu cytaty z tej książki będą oznaczane numerem strony w nawiasie kwadratowym. 
Goffman, Lévi-Strauss, Lévy-Bruhl, Mead, Otto, Piaget, Turner). Toteż analiza porównawcza transu w kultach vodun i katolicyzmie jawi się jako religioznawcze wyzwanie dla kulturoznawstwa. Już pierwsze słowa książki Bohuszewicza wskazują na wyraźnie ponaddyscyplinarny status podjętej w niej problematyki:

Kulturowe zjawisko owładnięcia przez duchy wydaje się budzić spore emocje, o czym przekonałem się podczas dyskusji z pewnym teologiem. Kiedy zaproponowałem eksperyment polegający na podaniu choćby jednego naturalistycznego (umysł/mózg, społeczeństwo, nerwica, schizofrenia itp.) wyjaśnienia tego zjawiska, teolog odparł z oburzeniem: „to wykluczone!” [s. 7].

Ten inicjalny akapit przekonywająco unaocznia względność dyscyplinarnych podziałów. Zarazem kulturoznawczy aspekt podjętej w książce problematyki mógłby być jeszcze wielorako potwierdzany, poprzestańmy jednak na dwóch zdaniach, które nawet po trzydziestu latach brzmią aktualnie: „Dopiero z czasem zrozumiano, że religia - obok moralności, sztuki, nauki - jest także jedną z dziedzin kultury”2; ,religia i religijność w polskich warunkach są bardziej dziedzictwem kulturowym niż sprawą osobistych przekonań i wyboru"3.

Autor niniejszego artykułu nie jest religioznawcą ani kulturoznawcą (lecz historykiem literatury staropolskiej ${ }^{4}$ ), dlatego ta publikacja nie będzie tradycyjnie rozumianą recenzją. W pierwszej kolejności chciałbym postawić pytanie o sprawę istotną, a mianowicie o adekwatność tytułu książki do jej zawartości. Tytuł zapowiada względnie równorzędny status katolicyzmu i kultów vodun, tymczasem zawartość dotyczy głównie religii Ameryki Środkowej, Afryki i Dalekiego Wschodu, toteż czytelnikowi Od opętania do rytuału wspólnoty charyzmatyczne i egzorcyzmy mogą wydawać się tylko katolickim kontekstem ułatwiającym poznawanie religijnych praktyk potomków afrykańskich niewolników czy też Jakutów bądź Ewenków.

Jakież więc ,zagadnienia fundamentalne dla zrozumienia ludzkiej natury” i tym samym kultury zostają omówione? Poprzestańmy na ich pięciu sygnalnych ilustracjach: „drastyczne opisy transu i naukowy obiektywizm w równym stopniu świadczą o tłumieniu fascynacji zjawiskiem owładnięcia” [s. 8]; „Jednostka odczuwa rytualne zniewolenie jako zerwanie woli z działaniem" [s. 81]; „religia może nie tylko usuwać stresory, lecz także specjalnie je kreować i sztucznie podtrzymywać” [s. 89]; „,celem [haitańskiego] rytuału nie jest tworzenie konwencji, ale poradzenie sobie z - negatywnie wartościowanym - faktem ich istnienia” [s. 188]; „,należy pamiętać o potencjalnej obecności transu w rytuale perfomatywnym, którego uczestnik znajduje się pod presją związaną z wykonywaniem niezakodowanej przez siebie roli, z alienacją, w której $[\ldots]$ «aktor robi w sobie miejsce dla uporządkowanego systemu znaków [...]»" [s. 207]. To oczywiście jedynie przykłady dowodzące, że religioznawcza książka może stanowić wyzwanie dla kulturoznawców...

\footnotetext{
${ }^{2}$ A. Bronk, Postowie [w:] G. Lanczkowski, Wprowadzenie do religioznawstwa, thum. A. Bronk, Warszawa 1986, s. 134.

${ }^{3}$ M. Filipiak, Religioznawstwo. Zagadnienia wybrane, Rzeszów 1989, s. 6.

${ }^{4}$ Dlaczego więc historyk literatury staropolskiej odważa się pisać o kulturoznawczym wyzwaniu związanym z religioznawczą książką? Ponieważ nie ma, a przynajmniej nie chce mieć dyscyplinarnych klapek na oczach (i zarazem nie skrywa, że osobiście zna Jakuba Bohuszewicza).
} 
W pierwszej kolejności należy określić metodę badań transu. W książce opatrzonej podtytułem Pojęcie i praktyka transu w kultach vodun $i$ katolicyzmie niejako siłą rzeczy przeważa metoda porównawcza. Jej charakter najkrócej oddają słowa Haliny Janaszek-Ivaničkowej: „Porównanie [...] nie może być żadnym wyróżnikiem, stanowi bowiem podstawę wszelkiej wiedzy"5. Potwierdza to choćby (najogólniej rozumiany) strukturalizm z jego inspiracją językoznawstwem, a zwłaszcza fonologią - subdyscypliną poniekąd konstytuowaną porównywaniem dźwięków ludzkiej mowy. Stanisław Jakóbczyk, autor książki Porównywanie. O procedurach naukowych filologii, pisze: ,[...] dla nauk humanistycznych porównanie to najmocniejsza, optymalnie spełniająca kryteria naukowości metoda badań - jednak inne nauki mają «mocniejsze» metody, toteż można mówić o «metodologicznej przypadłości humanistyki» w ogóle, a filologii w szczególności” ${ }^{6}$. Na szczęście dla religioznawstwa jego część „,metodologicznej przypadłości humanistyki” jawi się jako ułomność tylko umiarkowana.

Książka Od opętania do rytuatu może być czytana jako studium porównawcze. Co w niej jest przedmiotem porównania? Nie tylko tytułowe „pojęcia i praktyki transu" w ich dwóch religijnych formach (kulty vodun i katolicyzm), lecz również doprawdy liczne teorie religioznawcze. Autor nie dokonuje jednak ich prostego przeglądu, ale w umiejętny sposób wykorzystuje stan badań z dziedziny religioznawstwa do podparcia swoich tez. Struktura książki jest bardzo czytelna (śródtytuły sprzyjają rozpoznaniu logiki autorskiego wywodu) oraz funkcjonalna, to znaczy została podporządkowana tytułowemu porównywaniu.

Porównywanie jest procesualne, można bowiem postrzegać je jako „weryfikację hipotezy o wielkości podobieństwa co najmniej dwóch obiektów"7. Ileż obiektów zostaje porównanych przez Jakuba Bohuszewicza? Strona tytułowa książki wskazuje, że dwa bądź cztery, jednak nie jest to jednoznaczne: kulty vodun mają swoje lokalne odmiany i cechy charakterystyczne dla poszczególnych kultur, na przykład ludów Syberii czy plemion Ameryki Północnej. Mniejsza jednak o samą liczbę porównywanych obiektów oraz ich znaczenie (pierwszoplanowe? drugoplanowe?), najważniejsze wydaje się bowiem to, że wszystkie one wielostronnie rozjaśniają swe tożsamości w ich wielorakich proporcjach współtworzonych przez to, co im wspólne, i to, co przeciwne ${ }^{8}$. Przyjęta w książce hipoteza głosząca, że kulty vodun i katolicyzm mają na tyle poważny „wspólny mianownik”, że mogą stać się przedmiotem religioznawczej analizy porównawczej, została potwierdzona obszernym wywodem:

${ }^{5}$ Cyt. za: S. Jakóbczyk, Porównywanie. O procedurach naukowych filologii, Poznań 1990, s. 5.

${ }^{6}$ Ibidem, s. 6.

${ }^{7}$ Ibidem, s. 80.

${ }^{8}$ „Nie tylko jednak formalizm stoi na przeszkodzie dialogu religijnego i nie tylko $\mathrm{z}$ tego powodu dialog $\mathrm{w}$ religii jest sprawą trudną. Jak nigdzie indziej chodzi w nim bowiem o to, aby przez dialog zmieniać samych siebie. Wymaga on więc nie tylko uznania, że inna religia mówi „w dobrej wierze”, lecz przede wszystkim dobrego rozeznania we własnej wierze i religijności”, M. Szulakiewicz, P. Roszak, Religie $w$ dialogu kultur - zaproszenie na kongres [w:] Religie $w$ dialogu kultur, red. M. Szulakiewicz, Toruń 2017, s. 12. 
Obie religie - vodun i katolickie chrześcijaństwo - zakładają możliwość ścisłego dostosowania stanów prywatnych do treści kanonicznych. Różnica polega na tym, że w kultach vodun mamy do czynienia z zasadą organizacyjną, która w santerii otrzymuje postać mitu. Nie spotykamy tu natomiast - jak w katolicyzmie - teologów takich jak Jean Gerson, Martín de Castañega czy Karl Stehlin, uznających trans za przejaw działania sił antyboskich. Z kolei konwencjonalny rytualizm istnieje na obrzeżach vodun, podczas gdy w potrydenckim katolicyzmie ma jasno wytyczony status w centrum rytuału. Mimo tej różnicy oba systemy dysponują rytuałem, w którym zakulisowy aktor podlega czasowej eliminacji, a wytyczne kan onu obejmują nie tylko zewnętrzne działania, ale i stany wewnętrzne, czemu subiektywnie odpowiada uczucie przymusu [...] [s. 210, wyróżnienie - K.O.].

Tak więc, zdawałoby się, niedorzeczne skojarzenie okazuje się początkiem drogi zwieńczonej rozważeniem ,zagadnień fundamentalnych dla zrozumienia ludzkiej natury" i związanej z nią kultury. W kontekście powyższego cytatu budzi się we mnie jednak pewna wątpliwość: czy faktycznie można mówić o „treściach kanonicznych” kultów vodun oraz o ich „wytycznych kanonu”? Czyż owe kulty mają swe księgi objawione oraz instytucjonalne struktury? Czy Kościół rzymsko-katolicki faktycznie znajdowałby w nich adekwatny odpowiednik? Projekcja rzymsko-katolickiej bądź chrześcijańskiej optyki religijnej na kulty vodun prowokuje nawet pytanie o kolonializm czy postkolonializm... Pojawia się pytanie: czy religioznawcze badanie kultów vodun może być postrzegane jako naukowy pogłos chrystianizacji pogańskich kultur - niejako siłą rzeczy oznaczającej kulturowe wykorzenienie? Przyjrzyjmy się tym dwóm zdaniom:

W kulturze vodun odrębność osoby manifestuje się tylko na planie kognitywnym, przy jednoczesnym braku idei wolnej woli i wydzielenia jednostki ze środowiska społeczno-przyrodniczego. W katolicyzmie natomiast rytualnie thumionym doznaniom woli odpowiada na planie antropologicznym pojęcie człowieka będącego dominum sui actus [s. 220, wyróżnienie - K.O.]

W kontekście Haiti czy Jakucji słowa „osoba”, „plan kognitywny”, „,idea wolnej woli” bądź ,jednostka” brzmią... egzotycznie. Czyżby wyrażała się w nich przemoc kulturowa Zachodu wobec kultów vodun? Jak przypomina Andrzej Bronk, ,,[...] jednym z częstszych zarzutów wysuwanych pod adresem religioznawstwa europejskiego jest stwierdzenie, że patrzy ono na religie pozachrześcijańskie poprzez pryzmat pojęć urobionych na gruncie chrześcijaństwa". Oczywiście „plan kognitywny” nie należy do „pojęć urobionych na gruncie chrześcijaństwa”, jednak problem kolonializmu pozostaje...

W książce Bohuszewicza porównywane są (najogólniej) kulty vodun i katolicyzm. Dlaczegoż akurat one? Czym byłoby tertium comparationis? Otóż wspólnoty charyzmatyczne oraz egzorcyzmy współtworzą coś w rodzaju katolickiej części „wspólnego mianownika” dwóch zasadniczo odmiennych religii, które wbrew niemu mogą jawić się jako wręcz biegunowo przeciwne. Może o zasadniczej różnicy między nimi rozstrzygałby zakres racjonalizacji (jednak prymarnie nieracjonalnej)

${ }^{9}$ A. Bronk, op. cit., s. 144. 
Transcendencji? Zatem racjonalizacja w kultach vodun byłaby jedynie umiarkowana, w katolicyzmie bardziej zaawansowana?

Porównywanie splata się z materią aksjologiczną, gdyż ta apriorycznie zawiera się nawet już w samym wyborze tego, co ma być porównywane. Ponieważ jest szczególnie ciekawe? Z powodu wielorakich ograniczeń - jedynie dostępne? Społecznie szczególnie potrzebne? Bohuszewicz zadaje pytanie: czy kulty vodun i katolicyzm można traktować jako równorzędne sobie wyzwania poznawcze? A może dla polskiego religioznawcy pogański trans jest nieporównywalnie ciekawszy niż ten katolicki? Czy w badaniach wierzeń mieszkańców egzotycznych dla nas miejsc silniej ujawnia się aksjologiczna problematyka niż w badaniach katolickiej wiary wyznawanej przez większość Polaków? Nieprzypadkowo autor kulturowe (aby posłużyć się neutralnym terminem) zjawisko owładnięcia człowieka przez duchy nazywa (za Andrzejem Wiercińskim) nie „opętaniem”, lecz „posesją”. Tak słowa i rzeczy współtworzą siebie...

Jeszcze inne ,zagadnienie fundamentalne dla zrozumienia ludzkiej natury” i tym samym kultury wiąże się z materią metodologiczną, nią bowiem pozostaje wyróżnianie i zarazem przeciwstawianie analizy (nie-interpretacyjnego opisu) oraz interpretacji. Pod tym względem w książce Od opętania do rytuału możemy wyróżnić następujące problemy:

1. W koncepcji podróży przez poziomy kosmosu mamy do czynienia z mieszaniem kategorii transu jako stanu biologicznego i kategorii podróży - będącej interpretacyjnym konstruktem nałożonym na ów stan [s. 107].

2. Względność przeciwstawienia analizy oraz interpretacji; obrazuje ją następujący fragment (w którym pierwsza okazuje się drugą):

Rozróżnienie między adorcyzmem i egzorcyzmem i między szamanizmem i owładnięciem opiera się na tubylczych klasyfikacjach. [...] [Z]jawisko owładnięcia można badać na dwóch poziomach analizy. Na pierwszym poziomie mamy zdarzenie zakłócające równowagę społeczną, na drugim [wciąż na poziomie analizy?! - K.O.] koncepcje określające przyczynę problemu i metodę jego rozwiązania [s. 113].

3. Kontynuatorów tezy Mircei Eliadego - Luca de Heuscha oraz Gilberta Rougeta - „łączy tendencja do tworzenia typologii, co w praktyce oznacza bezkrytyczne korzystanie z tubylczych koncepcji badanych zjawisk [tj. transu szamańskiego i stanów posesywnych - K.O.]" [s. 115].

Tych kilka zdań, niezależnie od bezpośredniego kontekstu, dostatecznie sygnalizuje jeden z podstawowych problemów teorii literatury i całego literaturoznawstwa (i nie tylko!), mianowicie problem dualizmu metodologicznego, a nawet ontologicznego.

Polega on na każdorazowym odróżnieniu dwóch elementów w podejściu do tekstów będących przedmiotem interpretacji. Chodzi o opis i interpretację, ewentualnie: analizę i interpretację. [...] Uważam, że [...] podział na to, co jest analizą (opisem), i na to, co jest interpretacją, jest nie do utrzymania. Wszystko jest przedmiotem interpretacji. Jedyna uchwytna różnica [...] to różnica pomiędzy interpretacjami, o których interpretacyjności już zapomnieliśmy, a zatem tak się skonwencjonalizowały, że nie dostrzegamy już ich interpretacyjności, a interpretacjami, 
które wciąż są postrzegane jako interpretacje, albowiem nie uległy jeszcze owej konwencjonalizacji, są wciąż żywe i świeże ${ }^{10}$.

Skoro „wszystko jest przedmiotem interpretacji”?, wróćmy do tych trzech zdań poprzedzających ostatni cytat i zapytajmy:

Ad. 1. Czy również trans jako stan biologiczny nie jest, analogicznie do transu jako kategorii podróży, interpretacyjnym konstruktem?

Ad. 2. „Zdarzenie zakłócające równowagę społeczną” to nie przedmiot opisu, lecz już wprost wysłowiona interpretacja, gdyż zawczasu zostaje rozstrzygnięte to, co jeszcze jest „równowagą społeczną”, i co nią nie jest ${ }^{11}$.

Ad. 3. Jeśli to sami tubylcy formułują koncepcje transu szamańskiego i stanów posesywnych (a badacze rozwijający tezy Eliadego jedynie bezkrytycznie z nich korzystają), to znaczy, że owi tubylcy nie analizują transu szamańskiego i stanów posesywnych, lecz swoimi koncepcjami je interpretują, a zarazem przełamują dualizm podmiotu badań oraz ich przedmiotu.

Tak więc przynajmniej w tych trzech punktach trans szamański i stany posesywne potwierdzają zasadność teoretycznoliterackiego twierdzenia „wszystko jest przedmiotem interpretacji”.

Wydawałoby się, że problematyka zwerbalizowana polemiką teoretycznoliteracką w istocie rzeczy swoim zasięgiem obejmuje również religioznawstwo, w tym także badanie transu. Tego szczególnie wyraziście dowodzi Tabela 2 (Choroba i jej interpretacje w kultach vodun i w zachodniej medycynie) ze strony 167 . Bohuszewicz wyjaśnia ją następująco: „Chcąc uporządkować dyskusję [wokół problematyki opętanie - status outsidera - inicjacja vodunistyczna - K.O.], sporządziłem tabelę objawów neurofizjologicznych i towarzyszących im interpretacji formułowanych w dwóch systemach pojęciowych: vodun i medycyny zachodniej" [s. 166]. Dwa pierwsze przykłady (spośród pięciu omówionych) przytaczam w tabeli 1 .

Można w tym kontekście przywołać klasyczny problem studiów nad nauką zawarty w pytaniu: „W jaki sposób pakujemy świat w słowa?”, i w odpowiedzi wyłonionej z próbkowania gleby w Puszczy Amazońskiej. Istotna wydaje się analogia między próbkami gleby i pedokomparatorem a symptomami neurofizjologicznymi $\mathrm{i}$ ich interpretacjami formułowanymi w dwóch systemach pojęciowych: vodun oraz medycyny zachodniej. Tak jak kartonowe przegródki pedokomparatora sprawiają, że próbki gleby zostają przeniesione ze świata rzeczy do świata znaków, tak objawy neurofizjologiczne poprzez medium zachodniej wiedzy medycznej (z jej właściwą terminologią) są odczytywane jako symptomy religijnie znaczące. Uczestnik wyprawy badawczej w głąb Amazonii Bruno Latour wyjaśniał:

${ }_{10}$ A. Szahaj, Stawiński o interpretacji. Analiza krytyczna [w:] tegoż, O interpretacji, Kraków 2014, s. 115-116. Polemika: T.S. Markiewka, Fish to za mało. O ograniczeniach teorii Stanleya Fisha z perspektywy zwolennika konstruktywizmu, „Litteraria Copernicana. Konstruktywizm” 2016, nr 3(19), s. 57-71.

${ }^{11}$ Tu wyłącznie przykładowe sprzężenia zwrotne „słów” i „rzeczy”: zarówno w Czechosłowacji po wkroczeniu wojsk Układu Warszawskiego, jak i w Polsce po wprowadzeniu stanu wojennego dla jednych nastąpiła „normalizacja”, dla drugich była ona jej zaprzeczeniem: stłumieniem praskiej wiosny i jej socjalizmu z ludzką twarzą oraz przekreśleniem Sierpnia '80. 
Tabela 1. Choroba i jej interpretacje w kultach vodun i w zachodniej medycynie

\begin{tabular}{|l|l|l|l|}
\hline \multicolumn{1}{|c|}{ Pacjent } & \multicolumn{1}{|c|}{ Symptomy } & Interpretacja emiczna & \multicolumn{1}{c|}{ Diagnoza medyczna } \\
\hline $\begin{array}{l}\text { Mężczyzna } \\
\text { (24 lata) }\end{array}$ & $\begin{array}{l}\text { drgawki połączone } \\
\text { z utratą przytomności } \\
\text { skurcze mięśni ciała }\end{array}$ & $\begin{array}{l}\text { owładnięcie przez Ogu- } \\
\text { na } \\
\text { nękanie przez ducha } \\
\text { zmarłego }\end{array}$ & $\begin{array}{l}\text { napady toniczno-klo- } \\
\text { niczne } \\
\text { małe napady padaczko- } \\
\text { we; mioklonie }\end{array}$ \\
\hline $\begin{array}{l}\text { Kobieta } \\
(27 \text { lat })\end{array}$ & $\begin{array}{l}\text { zaburzenia orientacji } \\
\text { przestrzennej } \\
\text { poparzenia wynikłe } \\
\text { z kontaktu z ogniem } \\
\text { podczas rzutu choroby }\end{array}$ & $\begin{array}{l}\text { owładnięcie przez Ma- } \\
\text { rinnette, żeńską postać } \\
\text { w linii Petro }\end{array}$ & $\begin{array}{l}\text { napady czéściowe złożo- } \\
\text { ne, wtórnie uogólnione }\end{array}$ \\
\hline
\end{tabular}

Źródło: J. Bohuszewicz, Od opętania do rytuału. Pojęcie i praktyka transu w kultach vodun $i$ katolicyzmie, Jagiellońskie Monografie Religioznawcze, Wydawnictwo Uniwersytetu Jagiellońskiego, Kraków 2017, s. 167.

Instrument ten [pedokomparator] można dodać do listy pustych form, która w czasie tej ekspedycji robi się coraz dłuższa: obszar Edileusy podzielony na kwadraty dzięki numerom zapisanym na znacznikach przybitych do drzew; oznaczanie odwiertów za pomocą kompasu i topofila należących do René; numerowanie próbek i zdyscyplinowana sekwencja z protokołu nadzorowanego przez Héloïsę. Wszystkie te puste formy zostają ustawione po za zjawiskami, zanim się one pojawią, po to, aby mogły w ogóle się pojawić. Zjawiska niewyraźne w lesie, z powodu samej ich wielości, będą w końcu zdolne ukazać się, to znaczy odznaczyć się na nowym tle, które zmyślnie za nimi ustawiliśmy. Przed moimi oczami i przed oczami moich przyjaciół stosowne cechy objawiają się w pełnym świetle - równie białym, co pusty pedokomparator, czy papier milimetrowy, w każdym razie całkowicie odmiennym od głębokich zieleni i szarości rozległej, hałaśliwej puszczy [...]. Wypełnione ziemią kartoniki są na dobrej drodze, by stać się znakami, wiemy jednak, że to puste przegródki, zarówno takie jak tutaj, jak i słynne Mendelejowskie, są zawsze najważniejszą częścią schematu klasyfikacyjnego ${ }^{12}$ [wyróżnienie - K.O.].

Tak więc neurofizjologiczne symptomy transu byłyby niczym próbki gleby trafiające do dwóch pedokomparatorów: emicznego (rodzimego - naturalnego?) i medycznego (obcego - kulturowego)? Szczególnie ten drugi przypomina puste przegródki, w których czekają obce kultom vodun jednostki chorobowe - w religioznawczym rozpoznawaniu transu również one są ,ustawione poza zjawiskami, zanim się one pojawią, po to, aby mogły w ogóle się pojawić". Tak więc wiedza medyczna jest niczym tło ustawione za kultami vodun i dzięki niej podmiotowa interpretacja emiczna może zostać dopełniona, zrównoważona czy nawet przewyższona przedmiotową interpretacją medyczną. W badaniach transu odpowiednikiem przegródek gleboznawcy okazują się jednostki chorobowe. Niemożność nie tylko literaturoznawczego, lecz również religioznawczego przeciwstawiania analizy oraz interpretacji wyraziście werbalizuje Bronk: „,...]w nauce nie ma terminów czysto obserwacyjnych”, zaś „«fakty» religijne (jako należące do sfery kultury) niosą na sobie od początku znamię wysokiej teoretyczności”"13.

${ }^{12}$ B. Latour, Krążaca referencja. Próbkowanie gleby w Puszczy Amazońskiej [w:] Nadzieja Pandory. Eseje o rzeczywistości w studiach nad nauka, tłum. K. Abriszewski, Torun 2013, s. 80-83.

13 A. Bronk, op. cit., s. 139. 
Rzecz metodologicznie najważniejsza dotyczy jednak nie gleboznawstwa czy medycyny, lecz negowanego przez współczesną humanistykę dualizmu poznawania, w którym przeciwstawiane są: przedmiot opisu - opisowi, język - rzeczywistości pozajęzykowej, poznanie - temu, co jest poznawane. Faktycznie świat jest niezależny od języka? Jaka bowiem relacja łączy słowa i rzeczy? Słowa są powoływane do życia przez rzeczy czy też wręcz je wytwarzają? Znamienny przykład z sierpnia 1980: co dla jednych było strajkiem, dla drugich - nieuzasadnioną przerwą w pracy. Skoro nawet pojedynczym słowom może być dana moc stwarzania zwrotnie sprzężonych z nimi rzeczy, to cóż mówić o „,chorobie i jej interpretacjach w kultach vodun i w zachodniej medycynie"...

Triada rytuał-teatr-performans zawiera materię wręcz przepastną. Teoria „dzikiej świętości” - również ta wydaje się niezgłębiona. Analogicznie teatr transowy. Paul G. Bahn twierdził: „Szaman [społeczności tradycyjnych] jest w rzeczywistości showmanem [shaman is actually a showman]" [s. 132]. Jakże istotną problematykę poruszają następujące zdania:

Duchy wpadły w gniew, w związku z czym szamanka zaczęła bić uciekające kobiety [Ewenki K. O.]. Performans zakończył się niepowodzeniem [s. 133].

Analogie między owładnięciem i teatrem nie powinny przesłonić faktu, że w oczach publiczności opętany nigdy nie jest aktorem [s. 173].

[...] różnica między aktorem teatralnym a transowym zawiera się w tym, że pierwszy gra, drugi zaś przeżywa [s. 175].

Ta przepastna materia, najogólniej wytyczana przez trójkąt rytuał - teatr - performans, może być wyzwaniem dla badaczy polskiego teatru: od jedynego polskiego misterium, jakim była szesnastowieczna Historyja o chwalebnym Zmartwychstaniu Pańskim pióra Mikołaja z Wilkowiecka, przez jej inscenizacje Leona Schillera i Kazimierza Dejmka, aż po praktykę Scholi Teatru Węgajty wystawiania średniowiecznych dramatów liturgicznych, a więc ponowne włączenie do katolickich nabożeństw „teatru” (wygnanego z murów kościołów przez sobór w Trydencie).

Nie ma jednej prostej odpowiedzi na pytanie o to, czy msza święta jest teatrem. Analogicznie rzecz się ma z performatyką:

Sama msza święta posiada bez wątpienia wymiar perfomatywny - dzięki wierze w prawdziwość transsubstancjacji ${ }^{14}$.

W teologii katolickiej na określenie czynności liturgicznych, wykonywanych przez kapłana i jego ministrantów, używa się określenia ars celebrandi. Myślenie o osobie celebrującej mszę, że jest aktorem bądź performerem, było i jest $\mathrm{z}$ tego punktu widzenia nadużyciem. Jak nauczał św. Tomasz z Akwinu, kapłan we mszy konsekrację sprawuje in persona Christi (dosł. w osobie Chrystusa) ${ }^{15}$.

${ }^{14}$ P. Kencki, O widowiskach staropolskich [w:] Staropolskie zwierciadto. Dawne widowiska polskie z perspektywy wspótczesnej, P. Kencki, J. Kopciński (red.), Warszawa 2015, s. 58.

15 T. Kornaś, Aktor liturgiczny. Praktyka Scholi Teatru Węgajty [w:] Staropolskie zwierciadto..., op. cit., s. 126. 
Chrześcijański trójkąt rytuał - teatr - performans może być rozjaśniany (tzn. pogłębiany porównaniami) kultami vodun? I odwrotnie?

Książka Od opętania do rytuału, według zacytowanych na wstępie słów recenzji wydawniczej będąca przykładem pracy „odnoszącej się do zagadnień fundamentalnych dla zrozumienia ludzkiej natury" i, jak uważam, tym samym splecionej z nią kultury, może zabrać czytelnika w nieoczekiwane obszary wiedzy, wykorzystując takie dziedziny nauki jak literaturoznawstwo, filmoznawstwo, historia i politologia. Myśl badacza literatury zostanie skierowana na przykład w stronę Wesela z Chochołem i sennym transem bronowickich gości. Filmoznawca może pomyśleć o Rejsie Marka Piwowskiego: w wycieczkowej społeczności co prawda trudno doszukać się jakiejkolwiek transcendencji (mamy natomiast filmowe laboratorium ,mikrofizyki władzy"16), a przecież tragikomiczna i zarazem koszmarna wspólnota Polek i Polaków wpływa w ciemność nocy - opętana upiornym tańcem przebierańców. Historyk w książce Jakuba Bohuszewicza przeczyta, że moralność Malgaszy jest konceptualizowana nie jako wolny wybór, lecz jako ,uległość i uznanie obecności innych, penetrujących cię ludzi” [s. 33], w związku z czym może przyjść mu na myśl dziesiąty chorał Kornela Ujejskiego:

O! Panie, Panie! ze zgrozą świata

Okropne dzieje przyniósł nam czas,

Syn zabił matkę, brat zabił brata,

Mnóstwo Kainów jest pośród nas.

Ależ, o Panie! oni niewinni,

Choć naszą przyszłość cofnęli wstecz,

Inni szatani byli tam czynni;

O! rękę karaj, nie ślepy miecz!

Być może historyk po przeczytaniu wersów pieśni $Z$ dymem pożarów skojarzy Malgaszy z... rzezią szlachty galicyjskiej w 1846 roku. Politologowi z kolei może przyjść do głowy, że słowa: „Inni szatani byli tam czynni” (z pieśni Kornela Ujejskiego $Z$ dymem pożarów - niegdyś mającą nieoficjalny status jednego z trzech hymnów narodowych, obok Boże, coś Polskę... oraz Mazurka Dąbrowskiego), w swoich przemówieniach dwakroć wypowiedział Jarosław Kaczyński: 30 czerwca 2007 roku na konwencji PiS w Radomiu oraz 10 stycznia 2018 roku w Warszawie podczas 93. miesięcznicy smoleńskiej. Tak oto moralność Malgaszy (powtórzę: konceptualizowana jako „uległość i uznanie obecności innych, penetrujących cię ludzi”), chrześcijańskie opętanie i niechrześcijańskie owładnięcie, katastrofa oraz religia smoleńska przynajmniej potencjalnie współtworzą (nie tylko religioznawczą) przepastną głębię współbrzmień i tajemnic. Poniekąd nic w tym dziwnego; ojciec Tadeusz Rydzyk wszak powiedział: „Szatan się uwziął na Polskę, bo to jest najsilniejszy kraj katolicki w świecie"17. Zarazem nieprzypadkowo i wciąż jeszcze proroczo brzmią w moich uszach słowa tytułowej postaci satyrycznego programu Tadeusza Rossa Zulu-Gula: „Polska to bardzo dziwna kraj”.

${ }^{16}$ K. Obremski, Antysocjalistyczne badania kulturowe na ekranie: ,, Rejs” Marka Piwowskiego [w:] tegoż, Ciało - pleć - kultura, Toruń 2015, s. 87-108.

${ }^{17}$ P. Głuchowski, J. Hołub, Ojciec Tadeusz Rydzyk imperator, Warszawa 2013, czwarta strona okładki. 